\title{
Grain Size Analysis of the Sediments from Ogun River, South Western Nigeria
}

\author{
Itunu Comfort Okeyode ${ }^{1} \&$ Norbert Nnamdi Jibiri ${ }^{2}$ \\ ${ }^{1}$ Department of Physics, Federal University of Agriculture, Abeokuta, Nigeria \\ ${ }^{2}$ Department of Physics, University of Ibadan, Ibadan, Nigeria \\ Correspondence: Itunu Comfort Okeyode, Department of Physics, Federal University of Agriculture, Abeokuta, \\ Nigeria. E-mail: kamiyolejoy2000@yahoo.com
}

\author{
Received: July 22, 2012 Accepted: August 14, 2012 Online Published: September 6, 2012 \\ doi:10.5539/esr.v2n1p43 URL: http://dx.doi.org/10.5539/esr.v2n1p43
}

\begin{abstract}
The grain size analysis for thirty-two sediment samples from Ogun River was carried out. Mechanical sieving method using a Ro-tap shaker was chosen for the analysis. The cumulative frequency curve is obtained by plotting grain size (in phi scale) versus cumulative percent using the Probability paper. The phi values of the percentiles $5 \%, 16 \%, 25 \%, 50 \%, 75 \%, 84 \%$ and $95 \%$ were read off from the ogive curve that was plotted. These were used to calculate the statistical parameters of standard deviation, skewness, kurtosis and mean. 2.1 is the mean value for the grain size distribution within the analysed sediments with a graphic mean distribution for these sediments ranging from 1.09 to 2.90 phi, indicative of fine to medium grained sand. The standard deviation (sorting) shows a spread of of 0.54 to 1.42 phi and a mean value of 0.81 . Most of the samples are moderate to poorly sorted with only a few being moderately well sorted. The skewness values of the samples ranged from -0.25 to 0.53 , thus indicating the presence of fine fraction and coarse fraction in the particle population. The kurtosis is between 0.58 and 4.5 , indicating that $38 \%$ of the samples are leptokurtic, $41 \%$ are very leptokurtic, $6 \%$ are mesokurtic and $15 \%$ is very platykurtic.
\end{abstract}

Keywords: grain size analysis, statistical parameters, Ogun river

\section{Introduction}

Sediments are mechanically and/or chemically weathered rocks, they are loose, unconsolidated materials. They are eroded (picked-up) and transported (moved-along) to a new location. The most common mode of transport is the running water in rivers, ocean currents, etc. Winds, glaciers, and mass movements (such as landslides) are other less common modes of transport. River sediments originate from the erosion of near surface, exposed igneous, metamorphic or sedimentary rocks. Some of these are easily eroded, whereas others, especially the igneous and metamorphic rocks, are affected by streams only when altered in the surface (Joshua \& Oyebanjo, 2010). The sediments are then deposited and may eventually be buried to produce a sedimentary rock. The grain size distribution is a simple yet informative test routinely performed in soil mechanics to classify soils (Fredlund et al., 2000). The environmental interpretation of grain-size distributions found in sedimentary deposits has been, and still is, a fundamental goal of sedimentology (Patric \& Donald, 1985). The aim of this paper is to present the results of grain size analysis of Ogun river using 32 sediment samples. The samples were selected to take into consideration the whole length of the river.

\section{Materials and Methods}

\subsection{Study Area}

Ogun River in south western Nigeria passes through three states: Oyo, Ogun and Lagos state of Nigeria, (Figure 1). The main channel of this river originates at approximately $8^{\circ} 51^{\prime} \mathrm{N}, 3^{\circ} 38^{\prime} \mathrm{E}$ in the Oyo state of Nigeria around Ago Fulani, passing through part of Ogun state and enters Lagos Lagoon at latitude $6^{\circ} 35^{\prime} \mathrm{N}$ and longitude $3^{\circ} 25^{\prime}$ E. Ogun river and its tributaries is one of the series of the West African rivers, which do not drain into the Niger River system, but discharges into coastal lagoons and creeks bordering the Atlantic ocean (Sydenham, 1977). The major tributaries of Ogun river are the Oyan and Ofiki river. The river flows southwards to a distance of approximately $400 \mathrm{~km}$ and then discharges into the Lagos Lagoon through two distributaries $15 \mathrm{~km}$ North-East of Lagos. 


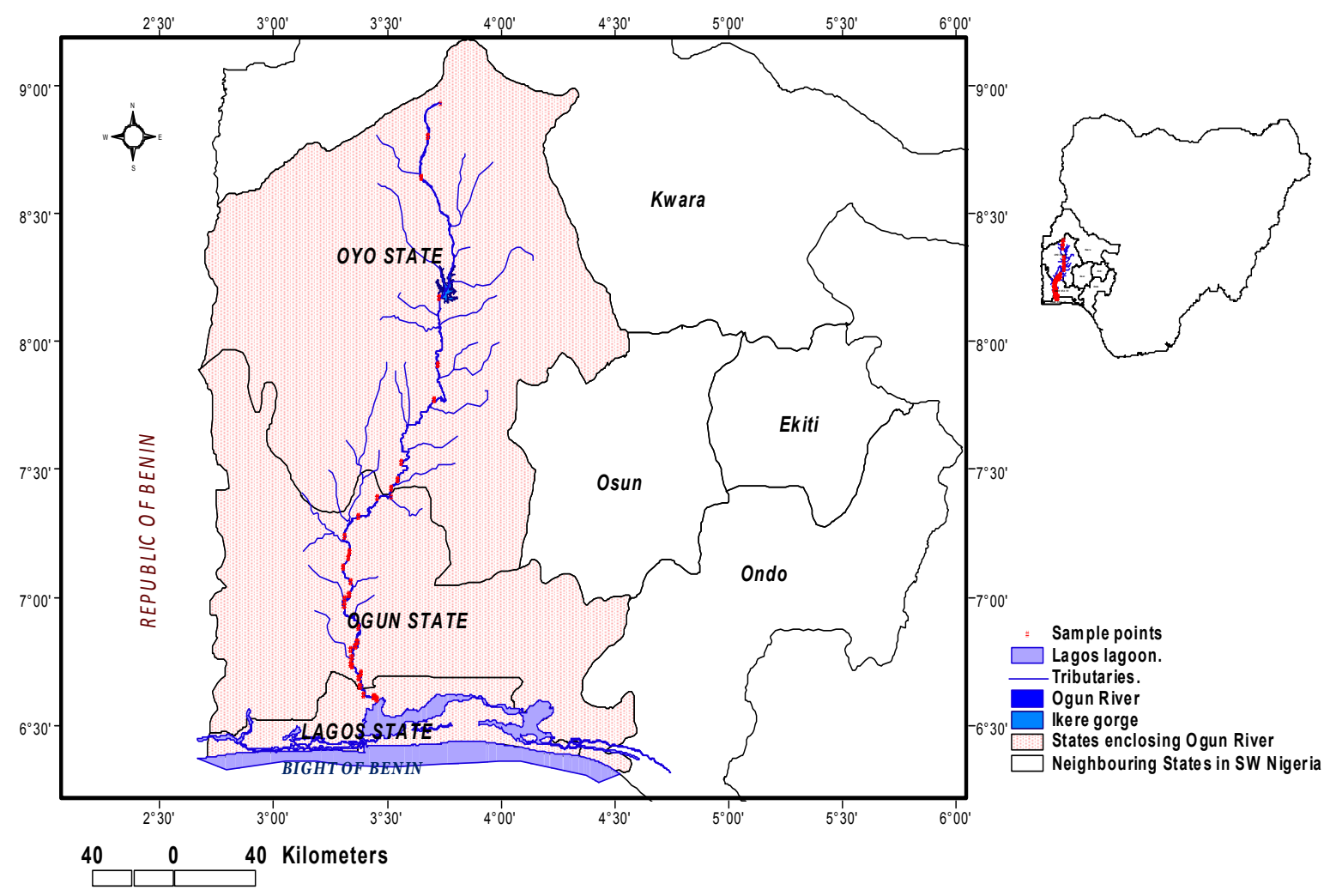

Figure 1. Map of South Western Nigeria showing the study area and the three states that the river traverses

The rocks in the study area consists of Precambrian basement rocks (Jones \& Hockey, 1964) made up of quartzite biotite schist, hornblende-biotite schist, granite and gneisses. The course of the river is controlled by the foliation and joints on these rocks causing them to form a trellis drainage pattern, particularly to the north of the area. The sedimentary rock sequences are from Cretaceous to Recent; the oldest of them, the Abeokuta formation, consists of grey sand intercalated with brown to dark grey clay (Jones \& Hockey, 1964). It is overlain by the Ewekoro formation, which typically contains thick limestone layers at its base. About $9 \mathrm{~km}$ upstream of Abeokuta town, there is a sharp change in land gradient, changing the river drainage from fast flowing to slow moving and leading to the formation of alluvial deposits overlying the sedimentary formation of Ewekoro, Ilaro and coastal plain sands in sequence towards the Lagos lagoon.

The Ogun River is used for many purposes, some of which include drinking, bathing, washing, fishing and the livelihood of many individuals which are derived from the activities in the river such as sanding and excavations. The sediments from the river are used in building houses. The river also acts as a sink to most organic wastes from abattoirs located along the course of the river (Sydenham, 1977).

\subsection{Sample Collection}

Figure 2 shows the locations where the sediment samples were collected along the course of the river. The river flows southwards covering a distance of approximately $400 \mathrm{~km}$. The location of each sampling point was taken using a Global Positioning System (GPS) receiver. Sediment samples were collected at each sampling area in the dry season around January through late April, 2007, at approximately $500-700 \mathrm{~mm}$ from the river banks. A total of 320 sediment samples were collected in this study. It is composed of 10 sediment samples from each of the 32 sampling locations along the entire course of the river. The distance between each location was about 300-500 $\mathrm{m}$ depending on local terrain and accessibility. At each sample location, about $200 \mathrm{~g}$ of the samples were collected. Each sample was packed in polytene bags, tied, labeled and brought to the laboratory for further analysis. Small quantities from each of the 10 samples in a given location were mixed together to forms a representative sample for that particular location. 


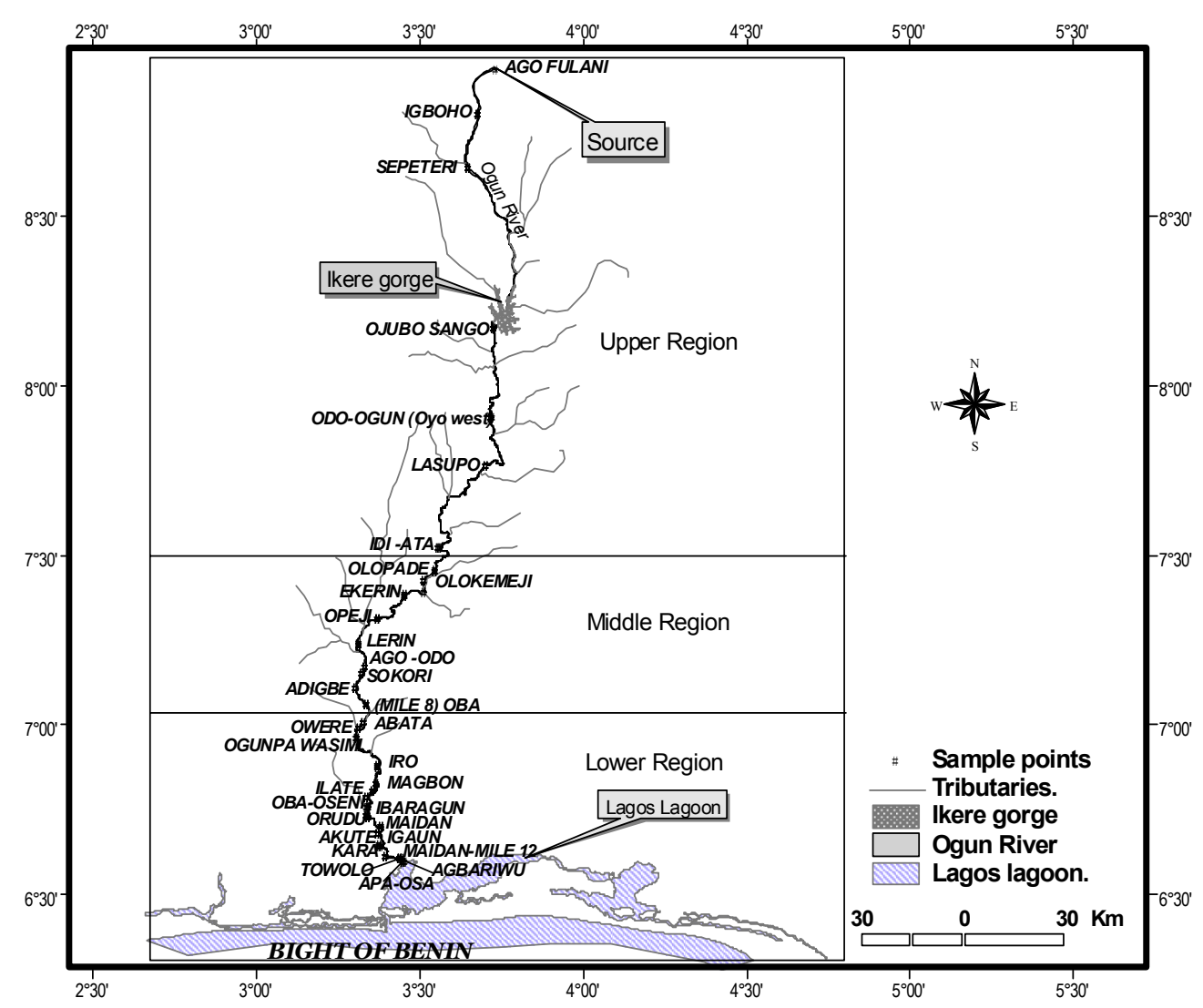

Figure 2. Map of the study area showing the sample locations along Ogun River

\subsection{Grain-Size Analysis}

Grain size analysis was carried out on 32 sediment samples collected along the course of the Ogun River. The analysis was carried out in the sedimentological laboratory of the Department of Geology, University of Ibadan.The analysis was aimed at measuring the individual grain sizes of the sediment samples. The samples were dried and the mechanical sieving method using a Ro-tap shaker was chosen for the analysis.

About $100 \mathrm{~g}$ of each sample was disaggregated using a porcelain mortar and pestle. The disaggregated samples were thoroughly mixed and split into quarters. This was weighed in a meter balance (P20 model) with a precision $0.011 \mathrm{~g}$. Each sample was then mechanically sorted into a set of US mesh sieves of 2.00, 1.18, 0.85, $0.60,0.425,0.30,0.25,0.15,0.075$ and $0.063 \mathrm{~mm}$ and a receiving pan using a Ro-tap shaker. The fraction retained in each sieve and the pan was weighed in a balance and its weight recorded and tabulated. The percentage aggregate was visually estimated and expressed in percentage.

The individual, as well as the cumulative weight percentage, was calculated and recorded. The grain size (in phi) was then plotted on the abscissa while the individual sample weight (in \%) was plotted on the ordinate, thus forming a pictorial chart showing grain size distribution (histogram) and frequency curve for each sample. The cumulative frequency curve (ogive) is plotted on a probability graph paper by plotting the grain size (in phi scale). The phi values of the following percentile; $5 \%, 16 \%, 25 \%, 50 \%, 75 \%, 84 \%$ and $95 \%$ were read off from the ogive curve. These were used to calculate the statistical parameters of standard deviation, skewness, kurtosis, mean and median as shown below. Equations 1-4 (Folk \& Ward, 1957), are used to derive the various grain size parameters.

Median: This is the diameter corresponding to the $50 \%$ mark on the cumulative curve

Graphic mean

$$
M_{Z}=\frac{\varphi(16+50+84)}{3}
$$

Inclusive graphic standard deviation (Sorting) 
$<ø 0.35$

$\phi 0.35$ to $\phi 0.5$

$\phi 0.50$ to $\phi 0.71$

$\phi 0.71$ to $\phi 1.0$

$\phi 1.0$ to $\phi 2.0$

$\phi 2.0$ to $\phi 4.0$

$>\phi 4.0$

Inclusive graphic skewness

$\phi 1.0$ to $\phi 0.3$

$\phi 0.3$ to $\phi 0.1$

$\phi 0.1$ to $\phi-0.1$

$\phi-0.1$ to $\phi-0.3$

$\phi-0.3$ to $\phi-1.0$

Graphic kurtosis

$$
<ø 0.67
$$

ø 0.67 to ø 0.90

$ø 0.90$ to ø 1.11

ø 1.11 to ø 1.50

$ø 1.50$ to $\varnothing 3.00$

$>\varnothing 3.00$

$$
\frac{\phi(84-16)}{4}+\frac{\phi(95-5)}{6.6}
$$

Very well sorted

Well sorted

Moderately well sorted

Moderately sorted

Poorly sorted

Very poorly sorted

Extremely poorly sorted

$$
S_{K}=\frac{\phi 16+\phi 84-2 \phi 50}{2(\phi 84-\phi 16)}+\frac{\phi 5+\phi 95-2 \phi 50}{2(\phi 95-\phi 5)}
$$

Very fine skewed

Fine skewed

Near symmetrical

Coarse-skewed

Very coarse skewed

$$
K_{G}=\frac{\phi 95-\phi 5}{2.44(\phi 75-\phi 25)}
$$

Very Platykurtic

Platykurtic

Mesokurtic

Leptokurtic

Very leptokurtic

Extremely leptokurtic.

\section{Results and Discussions}

The statistical parameters obtained from grain size analysis (granulometric analysis) for 32 sediment samples were used for plotting the cumulative frequency and histogram. From this graphical plotting, statistical size frequency parameters such as the graphic mean (mean size), sorting, skewness and kurtosis were calculated using various percentile values (Table 1).

Parameters such as mean grain size, median, sorting, skewness and kurtosis were deduced from graphic representation (frequency curve and histogram of the data). The histogram plot and cumulative frequency curve (e.g for Igboho in Figures 3 and 4) shows the frequency of grains in each size class and give an immediate impression of the grain size distribution. Most of the sediments being considered are unimodal except for few ones that are nearly bimodal reveals that the sands were derived from a single source area.

\subsection{Graphic Mean}

The mean size is a function of:

the size range of available materials and amount of energy impacted to the sediment which depends on current velocity or turbulence of the transporting medium.

The mean value for the grain size distribution within the analysed sediments is 2.1. Graphic means distribution for these sediments range from 1.09 to 2.90 . This is indicative of fine-grained sand to medium grained sands. This suggests that the sediments were deposited under low energy condition, as sediments usually become finer with decrease in energy of the transporting medium (Folk, 1974; Eisema, 1981). 
Table 1. Percentile values for grain size analysis

\begin{tabular}{|c|c|c|c|c|c|c|c|}
\hline SAMPLE LOCATIONS & $5 \%$ & $16 \%$ & $25 \%$ & $50 \%$ & $75 \%$ & $84 \%$ & $95 \%$ \\
\hline IGBOHO & 1.9 & 2.2 & 2.3 & 2.55 & 3.7 & 3.9 & 4.2 \\
\hline SEPETERI & 1.95 & 2.25 & 2.35 & 2.55 & 3.15 & 3.8 & 4.1 \\
\hline OJUBO SANGO & -0.27 & 0.54 & 0.98 & 1.4 & 1.9 & 2.16 & 3.44 \\
\hline ODO-OGUN (OYO WEST) & 0.6 & 1.41 & 1.7 & 1.97 & 2.28 & 2.43 & 2.97 \\
\hline LASUPO & -0.27 & 0.54 & 0.98 & 1.4 & 1.9 & 2.16 & 3.44 \\
\hline IDI-ATA & 0.77 & 1.08 & 1.24 & 1.67 & 2.03 & 2.33 & 3.48 \\
\hline OLOPADE & 1.65 & 1.8 & 1.95 & 2.2 & 2.05 & 2.65 & 2.75 \\
\hline OLOKEMEJI & 1.8 & 2 & 2.15 & 2.45 & 2.75 & 3.15 & 3.9 \\
\hline EKERIN & -0.68 & 0.56 & 0.79 & 1.43 & 1.89 & 2.39 & 2.94 \\
\hline OPEJI & 1.4 & 1.8 & 1.9 & 2.2 & 2.75 & 3.25 & 3.9 \\
\hline LERIN & 1.9 & 2.3 & 2.4 & 2.6 & 3.2 & 3.8 & 3.9 \\
\hline AGO-ODO & -0.82 & -0.08 & 0.35 & 1.13 & 1.92 & 2.22 & 3.66 \\
\hline SOKORI & 1.45 & 1.8 & 1.9 & 2.2 & 2.45 & 2.6 & 3.75 \\
\hline ADIGBE & 0.74 & 1.54 & 1.82 & 2.37 & 2.85 & 3.07 & 3.78 \\
\hline MILE 8(OBA) & -0.02 & 0.58 & 0.98 & 1.64 & 3.78 & 3.87 & 3.91 \\
\hline ABATA & 1.85 & 2.05 & 2.1 & 2.35 & 2.8 & 3.15 & 3.8 \\
\hline OWERE & 0.6 & 1.41 & 1.7 & 1.97 & 2.28 & 2.43 & 2.97 \\
\hline OGUNPA WASIMI & 0.26 & 0.32 & 0.65 & 1.27 & 1.86 & 2.27 & 3.29 \\
\hline IRO & 1.85 & 2.2 & 2.25 & 2.6 & 3.6 & 3.9 & 4.1 \\
\hline MAGBON & 0.74 & 1.54 & 1.82 & 2.37 & 2.85 & 3.07 & 3.78 \\
\hline ILATE & -0.04 & 0.41 & 0.76 & 1.26 & 1.61 & 1.89 & 3.53 \\
\hline OBA OSENI & -0.09 & 0.86 & 1.9 & 2.37 & 2.87 & 3.26 & 3.85 \\
\hline IBARAGUN & 1.5 & 2.4 & 2.45 & 2.65 & 3.15 & 3.55 & 3.95 \\
\hline ORUDU & 1.95 & 2.25 & 2.35 & 2.55 & 3.15 & 3.8 & 4.1 \\
\hline MAIDAN & 1.65 & 1.8 & 1.95 & 2.2 & 2.05 & 2.65 & 2.75 \\
\hline IGAUN & 0.05 & 0.79 & 1.02 & 1.47 & 1.92 & 2.11 & 2.97 \\
\hline AKUTE & 0.77 & 1.08 & 1.24 & 1.67 & 2.03 & 2.33 & 3.48 \\
\hline KARA & 1.9 & 2.3 & 2.4 & 2.6 & 3.2 & 3.8 & 3.9 \\
\hline MILE 12-MAIDAN & -0.02 & 0.58 & 0.98 & 1.64 & 3.78 & 3.87 & 3.91 \\
\hline TOWOLO & 0.5 & 1.07 & 1.27 & 1.6 & 1.88 & 1.98 & 2.53 \\
\hline AGBARIWU & -0.52 & 0.2 & 0.61 & 1.48 & 2.32 & 2.81 & 3.51 \\
\hline APA OSA & 0.69 & 1.32 & 1.67 & 1.99 & 2.3 & 2.53 & 2.94 \\
\hline
\end{tabular}

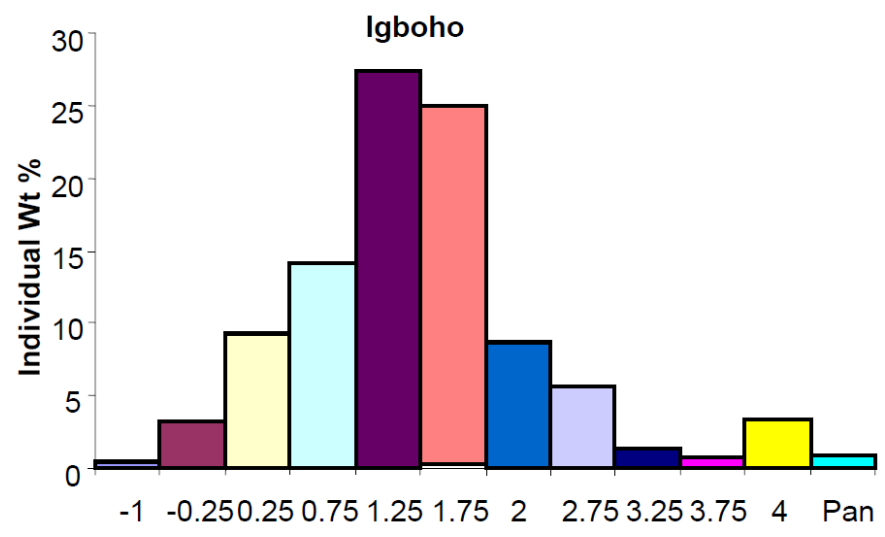

Figure 3. The histogram plot for Igboho 


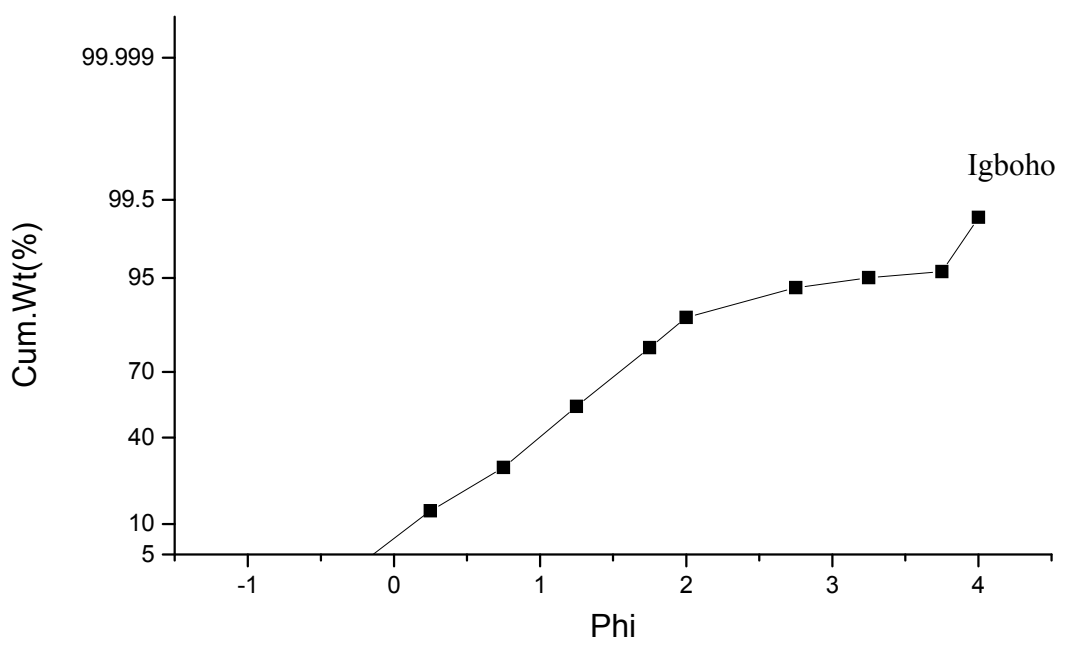

Figure 4. The cumulative frequency curve for Igboho

\subsection{Sorting}

This is a measure of the standard deviation which is the spread of the grain size distribution with respect to the mean. Sorting is the most useful grain size data since it gives an indication of the effectiveness of the depositional medium in separating grains of different classes.

The analysed sediments show a standard deviation of 0.54 to 1.42 and a mean value of 0.81 . According to Friedman (1961a), the various ranges of sorting in sandstones indicates the various environments of the sand (Table 2). From Table 3, most of the samples are moderate to poorly sorted with only a few, which are moderately well sorted. This is indicative of low to fairly high energy current (Friedman, 1961a; Blott \& pye, 2001).

Table 2. Classification of sands (Friedman, 1961a; Blott \& pye, 2001)

\begin{tabular}{|c|c|c|}
\hline $\begin{array}{l}\text { Ranges of values of standard } \\
\text { deviation (申units) }\end{array}$ & Sorting class & Environments of sandstones \\
\hline$<0.35$ & Very well sorted & $\begin{array}{l}\text { Coastal and lake dunes; many beaches (foreshore), } \\
\text { common on shallow marine shelf. }\end{array}$ \\
\hline $0.35-0.50$ & Well sorted & $\begin{array}{l}\text { Most beaches(foreshore); shallow marine shelf, many } \\
\text { inland dunes }\end{array}$ \\
\hline $0.50-0.80$ & $\begin{array}{l}\text { Moderately well } \\
\text { sorted }\end{array}$ & $\begin{array}{l}\text { Most inland dunes; most rivers; most lagoons, distal } \\
\text { marine shelf }\end{array}$ \\
\hline $0.80-1.40$ & $\begin{array}{l}\text { Moderately } \\
\text { sorted }\end{array}$ & $\begin{array}{l}\text { Many glacio-fluvial settings; many rivers; some lagoons; } \\
\text { some distal marine shelf. }\end{array}$ \\
\hline $1.40-2.00$ & Poorly sorted & Many glacio-fluvial settings \\
\hline $2.00-2.60$ & $\begin{array}{l}\text { Very poorly } \\
\text { sorted }\end{array}$ & Many glacio-fluvial settings \\
\hline$>2.60$ & $\begin{array}{l}\text { Extremely } \\
\text { poorly sorted }\end{array}$ & Some glacio-fluvial settings \\
\hline
\end{tabular}

\subsection{Skewness}

This is a reflection of the depositional process. It is simply a measure of the symmetry of the distribution. Skewness is useful in environmental diagnosis because it is directly related to the fine and coarse tails of the size distribution, and hence suggestive of energy of deposition.

The skewness values of the samples ranges from -0.25 to 0.53 , thus indicating the presence of fine fraction and coarse fraction in population of particles. The positive values indicate skewness towards the finer grain sizes and the negative values indicating skewness towards the coarser grain sizes. The analysed samples are skewed towards the finer grain sizes, typical of river sediments. 


\subsection{Kurtosis}

This is a measure of the peakedness of the curves towards the coarser grain sizes. The samples are predominantly leptokurtic, that is, the central portions are better sorted at the tails (Table 3). In numerical terms, the range of kurtosis is between 0.58 and 4.51 , typifying that $38 \%$ of the samples are leptokurtic, $41 \%$ are very leptokurtic, $6 \%$ are mesokurtic and $15 \%$ is very platykurtic. This strongly suggests a fluvial or tidal environment, confirming that the sands are river deposited.

Table 3. Summary of results obtained from grain size analysis and its interpretation

\begin{tabular}{|c|c|c|c|c|c|c|c|}
\hline Sample & $\begin{array}{l}\text { Median, } \\
\phi\end{array}$ & $\begin{array}{l}\text { Mean, } \\
\phi\end{array}$ & $\begin{array}{l}\text { Mode, } \\
\phi \\
\end{array}$ & $\begin{array}{l}\text { S.D } \\
\phi\end{array}$ & $\begin{array}{l}\text { Skewness, } \\
\phi\end{array}$ & $\begin{array}{l}\text { Kurtosis, } \\
\phi\end{array}$ & Interpretation \\
\hline Igboho & 1.48 & 2.88 & 0.84 & 0.77 & 0.51 & 0.67 & Moderately sorted, fine skewed and very platykurtic. \\
\hline Sepeteri & 1.97 & 2.86 & 2.75 & 0.71 & 0.53 & 1.1 & Moderately sorted, near symmetrical, and leptokurtic \\
\hline Ojubo Sango & 1.4 & 1.37 & 1.75 & 0.97 & 0.02 & 1.66 & $\begin{array}{l}\text { Moderately sorted, near symmetrical and very } \\
\text { leptokurtic }\end{array}$ \\
\hline $\begin{array}{l}\text { OdoOgun } \\
\text { (Oyo West) }\end{array}$ & 1.97 & 1.94 & 2.75 & 0.62 & -0.13 & 1.67 & $\begin{array}{l}\text { Moderately well sorted,Coarse skewed and very } \\
\text { leptokurtic }\end{array}$ \\
\hline Lasupo & 1.4 & 1.37 & 2.75 & 0.97 & 0.02 & 1.66 & $\begin{array}{l}\text { Moderately sorted, near symmetrical, and very } \\
\text { leptokurtic }\end{array}$ \\
\hline Idi -Ata & 1.67 & 1.69 & 1.75 & 0.72 & 0.2 & 1.4 & Moderately sorted, fine skewed and leptokurtic \\
\hline Olopade & 1.64 & 2.22 & 1.75 & 0.38 & 0.03 & 4.51 & $\begin{array}{l}\text { Moderately sorted, near symmetrical and extremely } \\
\text { leptokurtic }\end{array}$ \\
\hline Olokemeji & 1.67 & 2.53 & 4 & 0.61 & 0.3 & 1.43 & $\begin{array}{l}\text { Moderately well sorted,coarse skewed and very } \\
\text { leptokurtic }\end{array}$ \\
\hline Ekerin & 1.43 & 1.46 & 1.25 & 1.01 & -0.05 & 1.35 & Poorly sorted, near symmetrical and loptokurtic \\
\hline Opeji & 1.4 & 2.42 & 1.75 & 0.74 & 0.4 & 1.21 & Moderately sorted, near symmetrical and leptokurtic \\
\hline Lerin & 1.4 & 2.9 & 1.75 & 0.66 & 0.32 & 1.02 & Moderately sorted, near symetrical and leptokurtic \\
\hline Ago-Odo & 1.13 & 1.09 & 1.25 & 1.26 & 0.03 & 1.17 & Poorly sorted, near symmetrical and leptokurtic \\
\hline Sokori & 1.4 & 2.2 & 1.75 & 0.55 & 0.17 & 1.71 & $\begin{array}{l}\text { Moderately well sorted,coarse skewed and very } \\
\text { leptokurtic }\end{array}$ \\
\hline Adigbe & 2.37 & 2.33 & 2.75 & 0.84 & -0.08 & 1.21 & Moderately sorted, near symmetrical and leptokurtic \\
\hline Mile 8 (Oba) & 1.64 & 2.03 & 4 & 1.42 & 0.26 & 0.58 & Poorly sorted, fine skewed and very platykurtic \\
\hline Abata & 1.97 & 2.52 & 2.75 & 0.57 & 0.47 & 1.14 & $\begin{array}{l}\text { Moderately well sorted, near symmetrical and } \\
\text { leptokurtic }\end{array}$ \\
\hline Owere & 1.97 & 1.94 & 2.5 & 0.62 & -0.13 & 1.67 & $\begin{array}{l}\text { Moderately well sorted,coarse skewed and very } \\
\text { leptokurtic }\end{array}$ \\
\hline $\begin{array}{l}\text { Ogunpa } \\
\text { wasimi }\end{array}$ & 1.27 & 1.29 & 1.25 & 0.95 & 0.18 & 1.03 & Moderately sorted, fine skewed and mesokurtic \\
\hline Iro & 1.97 & 2.9 & 2.75 & 0.77 & 0.43 & 0.68 & Poorly sorted, fine skewed and very platykurtic \\
\hline Magbon & 2.37 & 2.33 & 1.75 & 0.84 & -0.08 & 1.21 & Moderately sorted, near symmetrical and leptokurtic \\
\hline Ilate & 1.26 & 1.19 & 1.25 & 0.91 & 0.06 & 1.72 & $\begin{array}{l}\text { Moderately sorted, near symmetrical and very } \\
\text { leptokurtic }\end{array}$ \\
\hline Oba Oseni & 2.37 & 2.06 & 2.75 & 1.2 & -0.25 & 1.66 & Poorly sorted, coarse-skewed and very leptokurtic \\
\hline Ibaragun & 2.37 & 2.87 & 0.72 & 0.66 & 0.31 & 1.43 & $\begin{array}{l}\text { Moderately sorted, near symmetrical and very } \\
\text { leptokurtic }\end{array}$ \\
\hline Orudu & 1.97 & 2.86 & 2.5 & 0.71 & 0.53 & 1.1 & $\begin{array}{l}\text { Moderately sorted, near symmetrical and very } \\
\text { leptokurtic }\end{array}$ \\
\hline Maidan & 1.64 & 2.22 & 2.82 & 0.38 & 0.03 & 4.51 & $\begin{array}{l}\text { Moderately sorted, near symmetrical and extremely } \\
\text { leptokurtic }\end{array}$ \\
\hline Igaun & 1.47 & 1.46 & 1.75 & 0.77 & $-0.01^{`}$ & 1.33 & Moderately sorted, near symmetrical and leptokurtic \\
\hline Akute & 1.67 & 1.69 & 2.75 & 0.72 & 0.2 & 1.4 & Moderately sorted, fine skewed and leptokurtic \\
\hline Kara & 1.4 & 2.9 & 2.75 & 0.66 & 0.32 & 1.02 & Poorly sorted, Fine skewed and very platikurtic \\
\hline $\begin{array}{ll}\text { Mile } & 12 \\
\text {-Maidan } & \end{array}$ & 1.64 & 2.03 & 1.75 & 1.42 & 0.26 & 0.58 & Poorly sorted, fine skewed and very platykurtic \\
\hline Towolo & 1.6 & 1.55 & 1.75 & 0.54 & -0.12 & 1.36 & $\begin{array}{l}\text { Moderately well sorted, coarse- skewed and } \\
\text { leptokurtic }\end{array}$ \\
\hline Agbariwu & 1.48 & 1.5 & 2.75 & 1.26 & 0.01 & 0.97 & Poorly sorted, near symmetrical and mesokurtic \\
\hline Apa Osa & 1.99 & 1.96 & 2.75 & 0.64 & -0.13 & 1.5 & $\begin{array}{l}\text { Moderately well sorted, coarse- skewed and } \\
\text { leptokurtic }\end{array}$ \\
\hline
\end{tabular}




\subsection{Interpretation of Scatter Diagrams}

The scatter diagrams of skewness versus sorting and graphic mean (mean size) versus sorting, in Figures 5 and 6 respectively, showed the distribution of the sands as fluvial and river sands.

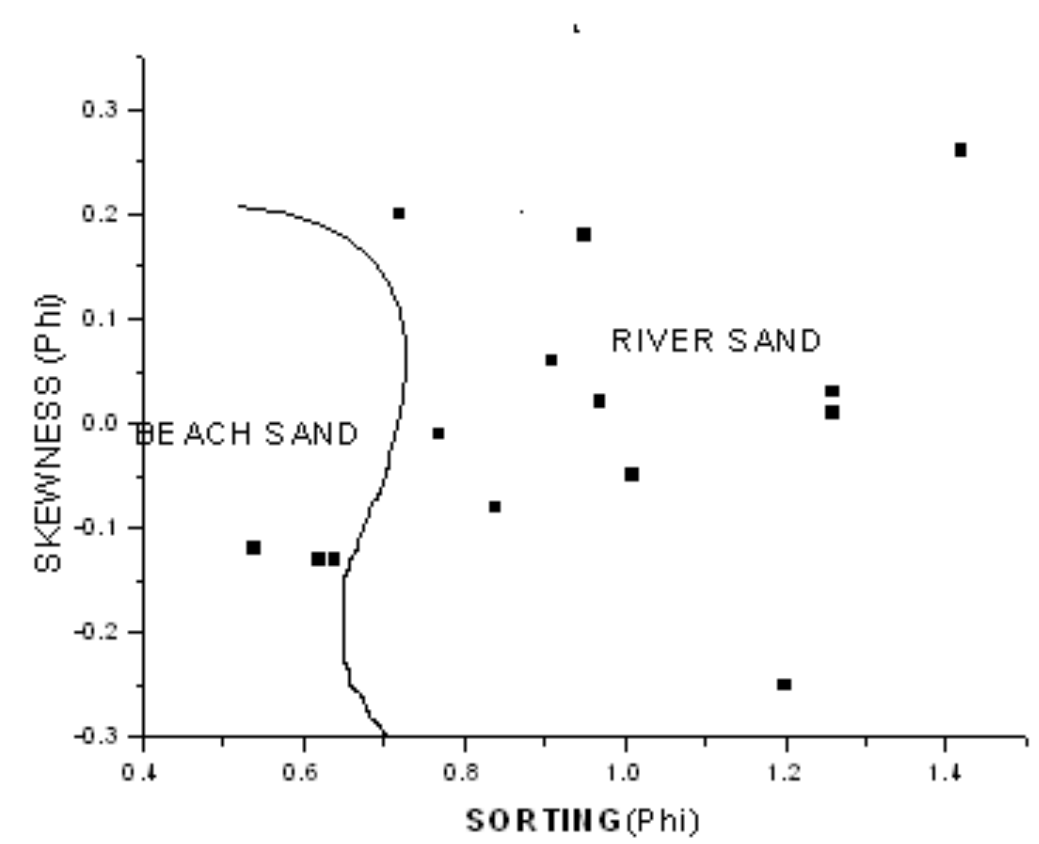

Figure 5. Scatter plot of skewness versus sorting (modified after Friedman, 1961b)

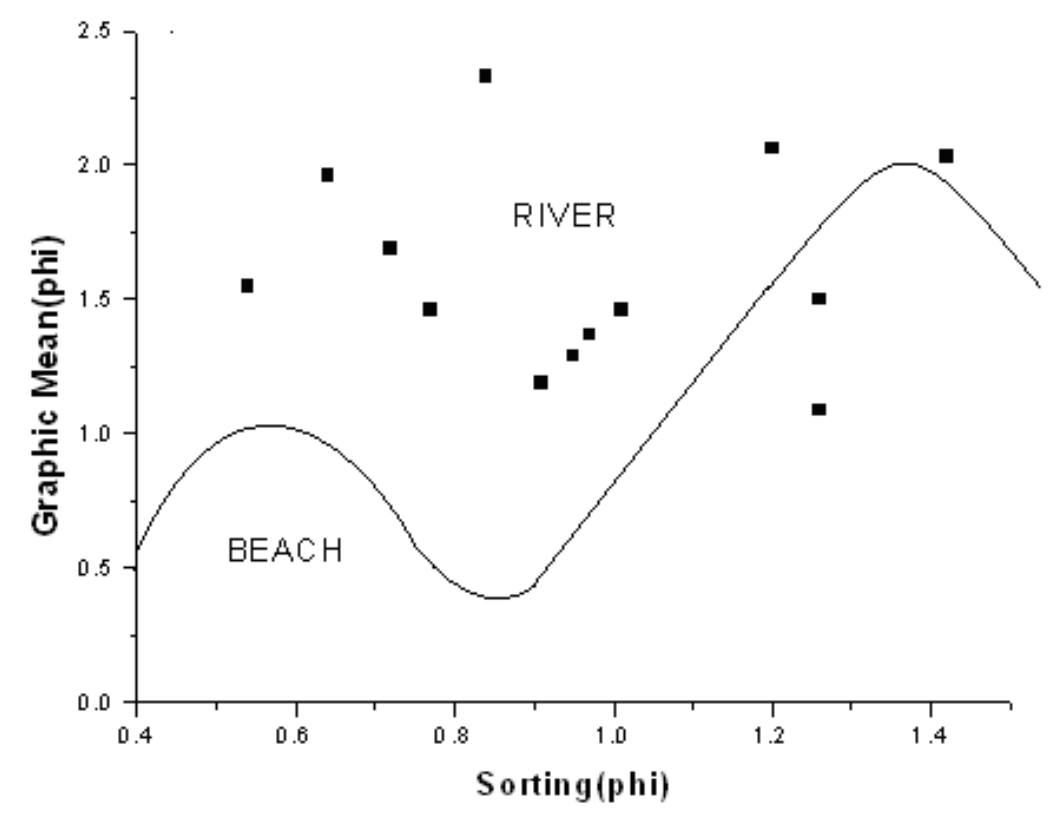

Figure 6. Scatter plot of graphic mean versus sorting (modified after Folk, 1974)

The unimodality of the grain size distribution chart with the exception of some nearly bimodal chart reveals that the sands were not derived from more than a single source area.

In general, and based on average values, the sediments are fine grained, moderately sorted, sands, associated with moderately high current flows in a fluvial environment. 


\section{Conclusion}

Sedimentological studies have been used to understand the provenance of the sediment samples. Nearly unimodal frequency distribution indicates a single provenance for the sediments. Textural studies indicate that the sediments belong to the fine to medium grained sand fraction, suggesting that the sediments were deposited under low energy condition, with the sediments being poorly sorted to moderately well sorted, indicating texturally immatured to sub-matured sediments of a fluvial environment.

\section{References}

Blott S. J., \& Pye, K. (2001). GRADSTAT: A grain size distribution and statistics package for the analysis of unconsolidated sediments. Earth surfaces processes and landforms, 26, 1237-1248.

Eisema, D. (1981). Supply and deposition of suspended matter in the north sea. Special Publication of the International Association of Sedimentologists, 5, 415-428.

Fredlund, M. D., Fredlund, D. G., \& Ward Wilson, G. (2000). An equation to represent grain size disribution. Can. Geotech J., 37, 817-827. http://dx.doi.org/10.1139/t00-015

Folk, R. L. \& Ward, W. C. (1957). Brazos river bar: A study in the significance of grain size parameters. $J$. Sediment. Petrol., 27, 3-26.

Folk, R. L. (1974). Petrology of sedimentary rocks. Austin Texas: Hemphili Publication, Company, p. 182.

Friedman, G. M., \& Sanders, J. E. (1978). Principles of sedimentology. New York: John Wiley Sons, p. 792.

Friedman, G. M. (1961a). Distinction between dune, beach and river sands from textural characteristics. Jour. Sed. Petrology, 31, 514-529.

Friedman, G. M. (1961b). On sorting, sorting coefficients and the log normality of the grain- size distributions of sandstones. Jour. Geol., 70, 737-753.

Jones, H. A., \& Hockey, R. D. (1964). The geology of Southwestern Nigeria. Bulletin, Geological Survey, 31-100.

Joshua, E. O., \& Oyebanjo, O. A. (2010). Grain-size and heavy mineral analysis of river Osun sediments. Australian Journal of Basic and Applied Sciences, 4(3), 498-501.

Sydenham, D. H. J. (1977). The qualitative composition and longitudinal zonation of the fish fauna of the river Ogun. Rev Zool. Afr., 91(4).

Patric, M., \& Donald, B. (1985). The effects of sediment transport on grain size distribution. Journal of Sedimentary Petology, 55(4), 0457- 0470. 